\title{
Processes of economic restructuring and functional transformations of an industrial city based on the city of Żory, Poland
}

\author{
Krystyna Magda-Żabińska \\ Higher School of Administration in Bielsko-Biała, Marcin Luter Square 7, 43-300 Bielsko-Biała, Poland \\ E-mail address: GEOMAG@gazeta.pl
}

\begin{abstract}
For decades the Silesian voivodeship has played a key role in the development of the economy of Poland. Its central area is occupied by an old industrial region which has been developed since the 19th century on the basis of coal mining and the processing of iron, zinc and lead ores. As a result of the political transformation of the country, after 1989, the region was faced with a difficult economic situation - a significant reduction in production was recorded and numerous unprofitable obsolete mines and steelworks were decommissioned. Since then, the economy of the Silesian region has been subject to restructuring and revitalization. This article presents this process as illustrated by a representative city - Żory. This is one of the oldest cities in the region which was established in the Middle Ages (1272). For centuries, its inhabitants were engaged in agriculture, fish breeding and trade. Its industrial development started with the construction of the ironworks at the beginning of the $19^{\text {th }}$ century, but the investments after the Second World War were of greatest importance to the city. At that time the "Fadom" factory, two hard coal mines - "Żory" and "Krupiński" - and a plant known as Zakład Tworzyw Sztucznych ERG (Synthetic Fibres Works "ERG") were constructed. After the political and economic changes of 1989 the economy of the city required urgent restructuring. The change of the function of the city of Żory proceeded gradually, but the creation of economic areas and zones, especially the establishment of the Jastrzębie Zdrój and Żory Subzone of the Katowice Special Economic Zone (1996) and Żory Industrial Park (2004), were of crucial importance to the development of the city. Over the past 20 years the city of Żory has changed from a city dependent on the extractive industries, without signs of a developed urban infrastructure, to a centre of a varied structure of production. Employment in industry and construction decreased from $65.5 \%$ to $36.3 \%$, and doubled in the case of services. The private sector currently comprises $75 \%$ of all economic entities - most of the companies are small or medium-sized enterprises up to 250 employees.
\end{abstract}

KEY WORDS: traditional industries, privatisation, special economic zone, industrial park, Silesian voivodeship

\section{Introduction}

The central part of the Silesian voivodeship is occupied by an old industrial region which for two centuries was founded on traditional heavy industries - hard coal mining and metallurgy. This region has played a key role in the Polish economy after World War II. In the systemic transformation period, after 1989, the region was placed in a difficult economic situation due to the new circumstances of the free-market economy a significant reduction in the production was recorded and numerous unprofitable obsolete mines and steelworks were decommissioned. For over twenty years the economy of the Silesian region has been subject to restructuring and revitalization (KLASIK, 1993; TKOCZ, 2001, 2007).

Restructuring involves the reconstruction of the structure of the economy, introduction of changes which aim to achieve development effects, whereas revitalization involves the restoration of spatial order in degraded districts of cities by contributing to the improvement in the quality of life of their inhabitants and reconstruction of social bonds. In the successfully implemented projects the following three ideal types of processes can be distinguished: 1) restructuring through a definite and planned collapse of some traditional industries 
such as mining, metallurgy and the development of new alternative sectors of the economy, especially the services sector; 2) restructuring through modernisation of some traditional industries and adapting them to the conditions of the world market; 3) restructuring through partial modernisation of the old sector and development of new, alternative and promising sectors of the economy, especially the innovative industries (SZCZEPAŃSKI, 2002).

Restructuring is a long-term process; it is also a very expensive undertaking, not only because of the investment costs, but also because of very high social costs. Revitalization is an opportunity to use comprehensive and modern solutions in the field of the development of urban areas which as a result of economic transformations, historical processes, as well as many other factors were destroyed and their importance for the development of the city was reduced.

The Silesian voivodeship consists of 71 cities. The majority of them were established in two historical periods: the Middle Ages and in the $19^{\text {th }}$ and $20^{\text {th }}$ century. The early Middle Ages were associated with the beginnings of the process of establishing settlements and the location of towns under German laws, the nineteenth- and twentieth-century phase of establishment of towns represents a period of development of industry, and in particular the development of mining in the area of Silesia. At present, four major concentrations of cities towns are distinguished within the borders of the Silesian voivodeship the Katowice conurbation, Rybnik agglomeration, Bielsko-Biała agglomeration and Częstochowa agglomeration (KRZYSZTOFIK, 2008).

Like other cities throughout Poland the cities of the voivodeship are subject to functional transformations in the period of systemic transformation (MAGDA-ŻABIŃSKA, 2010, 2011). Economic restructuring forces market processes and at the same time, to a greater extent, stimulates the transformation of industrial cities. The objective of this article is to present the restructuring transformations based on the city of Żory, a city that highly represents the said changes. Żory is one of 11 cities of the polycentric Rybnik agglomeration - it is an example of a city which was transformed from an industrial city into a post-industrial one. The formation of a city of this type is related to the evolution of the post-industrial society. The economic status continues to be the main principle of socio-spatial division, but the status of knowledge, and thus education starts to gain more and more importance. The progressing de- industrialisation is accompanied by an increase in the importance of the production of information, knowledge, its processing, which makes it a crucial economic and social function of the city (WĘCEAWOWICZ, 2007). The Statistical Yearbooks of the Silesian Voivodeship for the period from 1988 and 2009 were used as the primary source of information on the restructuring of the economy (ROCZNIK STATYSTYCZNY, 1988-2009).

\section{Development of Żory - from a medieval town to an industrial city}

In its recent history the city of Żory belongs to the group of cities of industrial monoculture. However, in its distant history Żory represents a type of town of medieval origin. Żory belonging to the southern part of Silesia underwent the stage of establishment of settlements in line with the patterns specified by German laws. Żory received town rights in 1272 . Prior to that, the Silesian voivodeship included only location towns such as: Racibórz (1217), Mikołów (1250), Bytom (1253), Cieszyn (1263), Wodzisław Śląski (1265). Thus, Żory is one of the oldest towns in the region. The town was founded next to the trail leading from Lower Poland to the west of Racibórz and further on to the Czech Republic. A very clear urban layout is preserved till this day which is highlighted by the existing fragments of defensive walls which is an element that confirms the former location. The established town welcomed settlers from the neighbouring villages as well as from the towns of Lower Silesia, in which urban communities were formed a bit earlier. Agriculture was, primarily, the basis for the existence of the inhabitants. Fish breeding also played an important role; some old sources provide information about the establishment of ponds. In later centuries drapery and linen industries played the most important role in Żory. This type of craftsmanship had a significant impact on the economic life of Żory as well as the trade which was developed parallel to it. However, only the local market was of utmost importance to Żory (CIMAŁA, 1997).

A new chapter for the function of Żory began in the early $19^{\text {th }}$ century. During this period, delayed industrialisation began: an ironworks belonging to Winckler (1830-1832), a Silesian magnate, was constructed and an iron foundry according to the Bulton-Watt system known as Odlewnia Żelaza i Fabryka Maszyn "Huta Paweł" ("Huta Pawel" Iron Foundry and Machinery Factory) was established. Poor development of industry along with the decline in the importance 
of craftsmanship resulted in the fact that in the second half of the $19^{\text {th }}$ century there was no cityformation factor in Żory. The social composition of inhabitants was changing to that typical for a new capitalist economy (CIMAŁA ET AL., 1994).

The period after the Second World War was the greatest time of development for Żory. The production activity was continued by "Huta Pawel", mill and brickworks. New plants established in the 1950s represented the electrical engineering industry (Manufacturing Plants for Signalling Devices). At the initial stage of the construction of the so-called Rybnik Coal Area, Żory became an area for investment, mainly of a residential nature, as well as for mining resources. The "Fadom" Coal Industry Residential Company, which also substantially contributed to the extension of other Silesian citie was well known. At the end of the 1970s the territorial development of Żory was noted; two mines were constructed in new annexed areas: "Żory" (decommissioned in 1996) and "Krupiński" (in operation to this day) The 1980s brought the development of one more segment of industrial production with the establishment of the Synthetic Fibres Works "ERG” (Zakład Tworzyw Sztucznych ERG).

\section{Restructuring the economy of Żory}

The most far-reaching functional changes in Żory took place in the most recent period. After 1990 , the process of privatisation of various economic areas began, and the economic changes taking place in Poland created opportunities for the creation and development of small businesses. The pace of change was very rapid because about 3,200 economic entities operated in Żory by the end of 1992. The leading industries included: general construction services, installation services, wholesalers and non-specialised shops. Moreover, new food business establishments emerged: "Smak" Agri-Food Processing Company, "Prez - Rol" Meat Establishments. In 1996 - 4,179 economic entities enlarging the services sector were registered, and in 2009 - 5,018, of which 103 represented the public sector and 4,915 the private sector.

The three large establishments were the first to start the privatisation process: Odlewnia Żeliwa (formerly "Huta Paweł" ironworks) Sp. z o.o., Zakłady Tworzyw Sztucznych Krywald ERG S.A., and PW "Fadom" (BUCHALIK \& GÓRECKI, 2010). The most effective and successful privatisation process was carried out in the former "Fadom" establishment. Austrian capital was invested in this process and the establishment was transformed into a company manufacturing PVC and aluminium window frames. To this day the company is known as AP Żory. Since 1991, when the production was launched, a very high demand for the company's products was observed. The economic condition of the establishment allowed Polish capital to completely take over the company in 2001. This is an excellent example of the restructuring of the environment close to the mining industry. AP Żory have a large share in the labour market in Żory itself as well as in the surrounding area.

\subsection{Jastrzębie-Zdrój and Żory Economic Sub-zone}

1996 was an important year for development. Żory joined the Jastrzębie-Zdrój and Żory Local Segment. The aim was to solve the problems resulting from the restructuring of the mining industry. The next step was to create the Jastrzębie Zdrój and Żory Economic Sub-zone as part of the Katowice Special Economic Zone (KSSE), as one of 14 special economic zones in Poland, established in order to accelerate the process of restructuring and creation of new employment opportunities in the region. The activity of the zone is foreseen until the end of 2020. The activities of the Jastrzębie-Zdrój and Żory Economic Sub-zone cover two areas: Warszowice Field and Wygoda Field. Currently, the whole area covers 245 ha. Since the creation of this sub-zone 5500 people have found a job there (KATOWICKA SPECJALNA STREFA, 2010). According to the idea of restructuring the area the investment projects outside the mining industry were placed there - the list of all investors is presented in Table 1.

\section{2. Żory Industrial Park}

The Żory Industrial Park (ŻPP) established in 2004 is another area of investment for small and medium-sized businesses. Górnośląska Agencja Przekształceń Przedsiębiorstw S.A. and the Żory commune partner the project. The Żory Industrial Park was established in the former area of "PEBEROW" Rybnik Coal Construction Company. The establishment of the ZPP was co-financed by the the European Regional Development Fund of the European Union and state funding under the Sectoral Operational Programme - Improvement of the Competitiveness of Enterprises. The purpose of the Park is to improve the business environment for entrepreneurs through the provision of a technical infrastructure and business consulting 
services. The offer of ZPP is particularly directed at entrepreneurs starting their business in the field of new innovative technologies.

The location of the Żory Industrial Park in the northern part of the city is advantageous: $2 \mathrm{~km}$ away from the national road No. 81 Katowice Wisła - Cieszyn, $10 \mathrm{~km}$ away from the A1 motorway junction, and $30 \mathrm{~km}$ away from the A4 motorway junction. So far, the degraded post-industrial area which was transformed into a modern technical infrastructure and made available to entrepreneurs from the sector of micro, small and medium-sized businesses was revitalized.
The Park includes a land property with an area of more than 8 ha, 6 facilities with a total area of $15,200 \mathrm{~m}^{2}$ designed as space for offices, production halls and warehouses. ZPP falls within a wide-ranging business services activity through: administrative and office services provided to companies, assistance in obtaining EU funding and seeking sources of financing, access to the services offered by GAPP S.A., among others, Loan Fund, Regional Innovation and Technology Transfer Centre and Entrepreneurship Support Centre, finding business partners (GÓRECKI, 2007).

Table 1. Investors acting in the Katowice Special Economic Zone (KSEZ)

\begin{tabular}{|l|c|c|}
\hline \multicolumn{1}{|c|}{ Investors } & Sector & Country of origin \\
\hline Arcen Polska Sp. z o. o. & machinery industry & Portugal \\
\hline Bratech Żurek Sp. j. & metal industry & Poland \\
\hline Elplast Sp. z o. o. & plastic products & Poland \\
\hline EXTRAL Sp. z o. o. & metal industry & Poland \\
\hline INSTANTA Sp. z o. o. & food industry & USA \\
\hline JP foam manufacturing Sp. z o. o. & automotive sector & Preat Britain \\
\hline Libet 2000 Sp. z o. o. & construction industry & Poland \\
\hline Majcher Łukasz & transport & Poland \\
\hline MCS Sp. z o. o. & automotive sector & Poland \\
\hline Mokate Sp. z o. o. & food industry & Poland \\
\hline Printex Lapot Sp. z o. o. & construction industry & Italy \\
\hline Sun-way Sp. z o. o. & metal industry & automotive sector \\
\hline TOORA POLAND S.A. in Nisko, Żory Production Plant & a & \\
\hline
\end{tabular}

\subsection{Local government reform}

The local government reform implemented in Poland in January 1999 was an important event for Żory. Żory was included in the group of 65 cities which have acquired the status of a county The city serves its new administrative function despite the smaller number of inhabitants than the required number of 100,000 inhabitants and similar aspirations of Rybnik. The restored institutional structure which is composed of the District Labour Office, Prosecutor's Branch Office, Regional Police Headquarters, and Revenue Office was also a decisive factor determining the importance and significance of the city of Żory. All these institutions were established in Żory in the 1990s.

\subsection{Use of European Union funding}

Poland's membership of the European Union also became a development impulse for Żory.
The city obtained EU funding for the modernisation of its infrastructure, becoming one of the cities that made the best use of EU funding in Poland. Up until 2009 PLN 354 million were acquired from the EU. Between 2006 and 2010 , the total investment capital from the city's budget reached PLN 447 million. In 2009 Żory took second place in Poland among the cities with county rights and thus was considered to be the largest investor in Silesia. The value of the investment projects undertaken in the field of municipal infrastructure per capita was the main assessment criterion. Żory has so far made use of 6 European Funds, thus confirming the pursuit of functional changes. In Żory the reforms dictated by the market economy tend towards the development of the services sector: trade and logistics, using the excellent location of the city in the region. The high level of investments requires a developed road infrastructure (KRYŃSKA, 2000). The city development strategy covers mainly the development of the transport network 
connecting the city to the A1 and A4 motorways and national road no. 81. EU funds were also allocated to culture, education, and recreation.

\subsection{Changes in the employment and investment structure}

The scale of the changes in the city is well reflected by comparing the employment structure in 1988 and 2009. Statistical analysis of the size indicates a significant diversification of employment: in 1988 the industry and construction sector employed $65 \%$ of more than 15000 people employed, whereas in 2009 it was only $36 \%$ of 12000 employees. Thanks to the restructuring of the economy the employment in the services sector grew from 31\% (1988) to $59 \%$ (2009) (Tab. 2). Currently, the services in Żory include mainly trade, repair, transport, and intangible services. The level of employment in services is higher than the total level in the Silesian voivodeship (Tab. 2). A high level of privatisation is also an important determinant of the changes; the private sector currently comprises $75 \%$ of all economic entities. Most of the companies are small, or medium-sized, enterprises of up to 250 employees.

Table 2. Labour market employment in \% (after Rocznik statystyczny województwa śląskiego, 1989-2009)

\begin{tabular}{|l|c|c|c|}
\hline \multirow{2}{*}{ Employment according to economic sector } & \multicolumn{2}{|c|}{ Żory } & Silesian voivodship \\
\cline { 2 - 4 } & 1988 & 2009 & 2009 \\
\hline Industry and construction & 65.5 & 36.3 & 43.8 \\
\hline Services & 10.8 & 25.6 & 25.0 \\
\hline Non-material services & 19.2 & 38.1 & 30.8 \\
\hline Agriculture & 0.0 & 0.0 & 0.4 \\
\hline Other sectors & 4,5 & 0,0 & 0,0 \\
\hline
\end{tabular}

Table 3. Capital expenditure by sectors in Żory in 2009 (after Rocznik statystyczny województwa śląskiego, 1989-2009)

\begin{tabular}{|l|c|}
\hline \multicolumn{1}{|c|}{ Sectors } & $\begin{array}{c}\text { Percent of the } \\
\text { total value }\end{array}$ \\
\hline Transport and warehouse management & 26.4 \\
\hline Real estate services & 21.4 \\
\hline Education & 20.4 \\
\hline Culture, entertainment, recreation & 11.6 \\
\hline Health care and social assistance & 9.6 \\
\hline Public administration & 8.4 \\
\hline Industry & 1.2 \\
\hline Construction & 1.0 \\
\hline
\end{tabular}

Żory also changed its investment structure by changing the functional structure. According to statistical data (Tab. 3), the sectors to which the largest amount of investment expenditure was allocated in 2009 included transport and warehouse management (26.4\%) and a new phenomenon among investments: real property market services $(21.4 \%)$, education $(20.4 \%)$. The lowest number of investments was recorded in the construction $(1.0 \%)$ and industry sectors $(1.2 \%)$. In the era of structural transformation a growing unemployment rate posed a serious problem; the highest in the voivodeship over a certain period of time. In 2006 the unemployment in Żory accounted for 15\%, and in $2009-9.8 \%$ compared to $9.4 \%$ in the whole of the Silesian voivodeship.

\section{Conclusion}

Over the past 20 years the city of Żory has changed from a city dependent on the extractive industry, without signs of a developed urban infrastructure to a centre of a varied structure of production. The Special Economic Zone and Industrial Park allowed to overcome the weakness of the local economy, namely its extreme dependence on the coal mine, a single large economic entity.

Żory has great potential for opportunities for development, provide all services adequate for the status of a county city. The city is a point of contact that links the Katowice conurbation, communities of the Rybnik Coal Area, the border area located by the border with the Czech Republic and the recreational and leisure areas of the Beskid Mountains. The characteristics of Żory that are conducive to the positive changes are as follows: 1) a high proportion of young people in the demographic structure, $70 \%$ of the population is of working age, and inhabitants aged from 16 to 39 account for $40 \%$; 2) attractive unoccupied investment land; 3 ) a non-degraded environment; 4) multi-century urban traditions.

The changes in the function of Żory occurred gradually. The co-creation of new economic zones such as the Jastrzębie-Zdrój and Żory Local Segment (1996), Jastrzębie-Zdrój and Żory Subzone of the Katowice Special Economic Zone 
(1996), Żory Industrial Park (2004) can be regarded as the phenomena that have changed the mono-functional centre to a significant extent. The importance and achievements of special economic zones are accurately reflected by the qualitative changes of Żory which are outlined in this article. New economic entities create new jobs, change the production structure and initiate changes in the areas adjacent to the economic zone.

\section{References}

Buchalik L., Górecki T. 2010. Leksykon Żorski. Muz. Miejskie, Żory.

Cimała B. 1997. Żory - zarys dziejów. Zarząd Miasta Żory, Żory.

Cimała B., Delewicz J., Porwoł P. 1994. Żory - zarys dziejów wypisy. Rada Miejska, Zarz. M. Żory, Tow. Mił. M. Żory, Żory.

Górecki T. 2007. Żorski Park Przemysłowy. Kalendarz Żorski, Żory.

Katowicka Specjalna Strefa Ekonomiczna, Podstrefa jastrzębskożorska. Kurier żorski, Żory, 2010.
Klasik A. 1993. Restrukturyzacja gospodarcza Górnośląskiego Okręgu Przemysłowego. Założenia wstępne. Biul. KPZK PAN, 162. Warszawa.

Kryńska E. (ed.) 2000. Polskie Specjalne Strefy Ekonomiczne. Wyd. Nauk. Scholar, Warszawa.

Krzysztofik R. 2008. Miasta. Aglomeracje miejskie. [in:] Tkocz M. (ed.) Województwo śląskie. Zarys geograficznoekonomiczny. Uniw. Śląski, WNoZ, Sosnowiec.

Magda-Żabińska K. 2010. Przemiany funkcjonalne Mielca. Kształt. środ. geogr. i ochr. przyr. na obsz. uprzem. i zurban., 42: 42-51.

Magda-Żabińska K. 2011. Żory w dobie przemian funkcjonalnych - główne tendencje. Kształt. środ. geogr. i ochr. przyr. na obsz. uprzem. i zurban., 43: 51-57.

Rocznik statystyczny województwa śląskiego. Urząd Statystyczny w Katowicach, Katowice 1988-2009.

Szczepański M. S . 2002. Opel z górniczym pióropuszem. Wyd. Śląsk, Katowice.

Tkocz M. 2001. Restrukturyzacja przemysłu regionu tradycyjnego. Wyd. Uniw. Śląskiego, Katowice.

Tkocz M. 2007. Zmiany w funkcjonowaniu górnictwa węgla kamiennego w Polsce po roku 1989. Acta Geogr. Silesiana, 2: 51-58.

Węcławowicz G. 2007. Geografia społeczna miast. PWN, Warszawa. 